\section{Effect of Antibiotics on the Phagocytic Activity of the Reticulo-Endothelial System}

IT was shown by Nicol and his co-workers 1,2 that cestrogens, both natural and synthetic, stimulate the phagocytic activity of the reticulo-endothelial system, while cortisone depresses phagocytosis, and also the total and differential white cell counts in the blood and the gamma-globulin level in the serum. On the other hand, if cortisone treatment is stopped, the depressant action of the cortisone can be reversed and converted into one of moderate stimulation by diethyl stilbœstrol; and, further, if cortisone and diethyl stilbœstrol are administered separately but at the same time, the depressant action of the cortisone is prevented and considerable stimulation of phagocytic activity occurs ${ }^{\mathrm{s}}$. According to Florey ${ }^{4}$ it is possible that some chemotherapeutic agents depend for their complete effectiveness on the action of phagocytes; he also states that in acute infections the organisms are generally killed or inhibited by the use of chemotherapeutic drugs.

The following research was designed to study the effect of antibiotics on the phagocytic activity of the reticulo-endothelial system to find out whether or not the phagocytes were actively stimulated and thus play an important part in the action of these drugs, and whether the results might be of interest in determining the choice of an antibiotic.

The present experiments were carried out on 120 male white mice (T.O. Swiss strain) of 18-25 gm. body-weight. The doses of the antibiotics and the routes of administration were arranged to be comparable with standard clinical and veterinary practice. Groups of 5-10 animals were used for assessing the effect of each antibiotic on the phagocytic activity of the reticulo-endothelial system, each animal receiving one dose of the antibiotic daily for six days. The phagocytic activity was then measured on the eighth day by the rate of disap. pearance of a known amount of carbon from the circulating bloods, the procedure being as follows. Each animal was given one intravenous injection of carbon of particle size $250 \mathrm{~A}$., the dose of the carbon being calculated on the basis of $16 \mathrm{mgm}$. per $100 \mathrm{gm}$. body-weight. Blood was then taken at short intervals during the first $30 \mathrm{~min}$. following the injection, and the concentration of the carbon in each blood sample was measured by an absorptiometer. The logarithmic values of the absorptiometer readings lie along a straight line when plotted against time, and the slope of the line has been taken as the measure of total body phagocytic activity or the phagocytic index, which is noted in the present communication by the symbol $K$.

Twenty-five of the animals were used as controls. They were given carbon only, and showed an average phagocytic index or $K$ value of $18 \pm 5 \cdot 8$.

Fifteen types of antibiotic were investigated, some given orally and others parenterally. The results are shown in Table 1. Compared with the control values, it can be seen that the antibiotics used have little or no effect on the phagocytic activity of the reticuloendothelial system. The low value shown for penethamate hydriodide is probably due to the toxic effect of this substance, since all the animals in this group showed general evidence of toxicity. The above results are at present being confirmed in a larger series of animals.
Table 1. EFfect of Various antibiotics on the Phagocytio Table 1. EFFECT OF VARIOUS ANTIBIOTICS ON THE PHAGOCXTIO
ACTIVIT OF THE RETICULO-ENDOTHELIAL SYSTEM

\begin{tabular}{|c|c|c|}
\hline Antibiotic used & $\begin{array}{c}\text { Route of } \\
\text { administration }\end{array}$ & $\begin{array}{c}\text { Phagocytic } \\
\text { index } \\
\text { (K value) }\end{array}$ \\
\hline $\begin{array}{l}\text { Crystalline penicillin } G \\
\text { Phenoxymethyl penicillin } \\
\text { Benzathine penicillin } \\
\text { Triplopen } \\
\text { Dibenzyldipenicillin } \\
\text { Penethamate hydriodide }\end{array}$ & $\begin{array}{l}\text { Subcutaneous } \\
\text { Oral } \\
\text { Oral } \\
\text { Subcutaneous } \\
\text { Subcutaneous } \\
\text { Subcutaneous }\end{array}$ & $\begin{array}{l}27 \pm 2 \cdot 6 \\
21 \pm 1 \cdot 6 \\
16 \pm 6 \cdot 4 \\
20 \pm 8 \cdot 5 \\
12 \pm 2 \\
9 \pm 2 \cdot 4\end{array}$ \\
\hline $\begin{array}{l}\text { Chlortetracycline } \\
\text { Tetracycline } \\
\text { Oxytetracycline }\end{array}$ & $\begin{array}{l}\text { Subcutaneous } \\
\text { Oral } \\
\text { Subcutaneous } \\
\text { Oral } \\
\text { Oral }\end{array}$ & $\begin{array}{l}18 \pm 3 \cdot 0 \\
12 \pm 2 \cdot 8 \\
18 \pm 5 \cdot 6 \\
17 \pm 3 \cdot 2 \\
14 \pm 5 \cdot 1\end{array}$ \\
\hline $\begin{array}{l}\text { Dihydrostreptomycin sulphate } \\
\text { Streptomycin sulphate } \\
\text { Viomycin } \\
\text { Erythromycin } \\
\text { Neomycin } \\
\text { Chloramphenicol }\end{array}$ & $\begin{array}{l}\text { Subcutaneous } \\
\text { Subcutaneous } \\
\text { Intraperitoneal } \\
\text { Oral } \\
\text { Subcutaneous } \\
\text { Oral }\end{array}$ & $\begin{array}{l}13 \pm 3 \cdot 6 \\
13 \pm 2 \cdot 6 \\
15 \pm 3 \cdot 6 \\
16 \pm 2 \cdot 9 \\
14 \pm 2 \cdot 8 \\
12 \pm 1 \cdot 6\end{array}$ \\
\hline Control values in 25 animals & 一 & $18 \pm 5 \cdot 8$ \\
\hline
\end{tabular}

In these investigations we gratefully acknowledge gifts of drugs from the Medical Directors of Messrs. Boots, Glaxo, Lederle, Eli Lilly, Parke Davis, Pfizer, Smith Kline and French and John Wyeth, and financial assistance from the Central Research Fund of the University of London.

I. A. Sewell

T. NICOL

Department of Anatomy, King's College,

London, W.C.2. May 8.

${ }^{1}$ Nicol, T., Helmy, I. D., and Abou-Zikry, A., Brit. J. Surg., 40, 160 (1852).

${ }^{2}$ Nicol, T., Snell, R. S., and Blbey, D. L. J., Brit. Med. J., ii, 800 (1956).

${ }^{3}$ Nicol, T., and Bilbey, D. L. J., Nature, 179, 1137 (1957).

"Florey, H., "General Pathology" (Lloyd-Luke, London, 1958).

${ }^{5}$ Biozzi, G., Benacerraf, B., and Halpern, B. N., Brit. J. Exp. Path., 34, 441 (1953).

\section{N-Terminal Histidine at the Active Centre of a Permeability Mechanism}

THE movement of glycerol across the membrane of the human erythrocyte is accelerated by a specific mechanism"-2, one of the "facilitated diffusion" systems ${ }^{3}$. The activity of this mechanism has previously been considered to be dependent on the presence of the thiol group of cysteine ${ }^{1}$. I wish to report evidence suggesting rather that the residue concerned is histidine, situated in a particular position, namely, at the amino-end of a polypeptide chain.

The evidence arises from two types of experiments : studies of the inhibition of the facilitated diffusion system by heavy metals and by other chemical reagents; and direct isolation of the $\mathrm{N}$-terminal histidine residue in such circumstances as to suggest that it has a role in the activity of the system.

The glycerol-facilitated diffusion system (or 'facilitator') is inhibited by traces $\left(10^{-7} M\right)$ of copper', which is probably bound at or near the 'active centre' of the facilitator'. The association constant of the complex formed between copper and the group at the active centre has now been measured. The method used involved reversing the copper inhibition by adding a copper chelating agent of known dissociation constant. The value obtained $\left(10^{10}\right)$ is close to that of the first-order association constant of the copper-histidine complex 4 . 